\title{
THE CONTRIBUTION OF UNIVERSITIES TO REGIONAL DEVELOPMENT
}

\author{
Tamara Grizane ${ }^{1}$, Inguna Jurgelane-Kaldava ${ }^{2}$ \\ ${ }^{1}$ Turiba University, Latvia \\ ${ }^{2}$ Riga Technical University, Latvia \\ tamara.grizane@inbox.lv
}

\begin{abstract}
It is neccessary for the Regional Universities (RU) to strengthen their regional role. The reason behind such trend is the increased economic and regional differences between regions which applies also to Latvia. The aim of this research is to define the contribution of the RU to the regional development. The research included analysis of scientific sources, correlation and analysis of variance. It was determined that there is a positive correlation 0.979 between the number of students of RU and corresponding regional Gross domestic product (GDP) per capita; thus the RU have a positive impact on the regional development while other drawbacks and problems exist.
\end{abstract}

Key words: regional development, higher education institutions, contribution.

\section{Introduction}

In previous periods the state policies and Regional Universities (RU) have been emphasising the reaching of specific national goals or knowledge acquir. At the same time, a research by the Organisation for Economic Co-operation and Development (OECD) (2007) has indicated the necessity to help the area in the vicinities around the RU, to cooperate with the aim of strengthening the regional role. The research results have showed that this is a tactic used by the wealthiest states - to develop regions 'by nurturing the unique assets and circumstances of each region' (OECD, 2007).

However, the global tendencies indicate that the overal economic and social disparity between the regions and cities is increasing (Beeson, 2010; Glaeser, Giacomo, \& Ponzetto, 2014; Chadwick, 2016). The regional development goal in Latvia, as well as in many other countries, is to ensure and enhance balanced regional development, while taking into consideration the unique aspects and opportunities of its separate regions (NAP, 2012).

The regional research in the United States (US) (over a period of almost 200 years) has indicated that the education increases the level of entrepreneurship, while ensuring positive impact on the unemployment and, as a result on the level of wealth (Glaeser, Giacomo, \& Ponzetto, 2014).

The priority of the National Development Plan of Latvia 2014-2020 (NAP) 'Development enhancing territories' was aimed on creation at the conditions for longterm, balanced economic development in the regions of Latvia with the aim of reaching sustainable development, strengthening regional capacity and using regions resources and advantages with the greatest effect (NAP, 2012).

Region Gross domestic product (GDP) per capita is an indicator portraying the regional disparities at the economic development level (it is estimated by summing the national and region GDP Nomenclature of Territorial Units for Statistics 3 (NUTS 3) differences per one inhabitant, while evaluating the proportion of regions population and expressed as percentage of GDP per capita). The reduction of regional GDP variance per capita indicate the differences in the economic development, while RU investment is the result of interaction of human capital and economics.

The interaction of human capital and economic development was analysed at both the micoeconomic (Odit, Dookhan \& Fauzel, 2010), as well as macroeconomic level (Bouaissa, 2009). The OECD (2007) report explicitly indicates the importance of the higher education in the development of the human capital. According to Bashir, Iqbal \& Zaman (2011), the education allows creating the elements necessary for the creation of human capital competency, knowledge, etc., but most importantly it is directed towards work to creat the economic value. The analysis of scientifical literature proves the interrelation of human capital and the GDP, thus indicating a possibility to use eduation indicators as indicators of human capital (Mankiw, Romer, \& Weil, 1992; McMahon, 1998).

In Latvia, the research on the interrelation of education and economic parameters has been carried out by multiple researchers - Baumanis (2004), Ekmanis (2005), Grizane, Sannikova \& Jasaitis (2017). Nonetheless, the authors underline that the overall number of research on the RU impact on the regional development is not sufficient and further studies are necessary.

Research object: the contribution of Regional Universities.

Research aim: define the contribution of the RU to the regional development.

Research tasks:

(1) To examine theory on the contribution of RU on the regional development;

(2) To investigate the regions and the RU;

(3) To evaluate the employment of the graduates, entrepreneurship activity, and loyalty to the region; 
(4) To determine the correlation between the GDP per person in the regions of Latvia and the corresponding number of RU students.

The research of scientific literature has allowed to determine that the impact of RU in the regional development can materialise as (1) economic and social impact spheres of a person; (2) economic and social spheres of the society (O'Carroll, Harmon, \& Farrell, 2006; Universities UK, 2015).

Investments in education might lead to increased personal income, however, according to Dr. Simon McGrath from Notingham University, specialising in international education and development, "when taking into account the real world occurences, it is a way too simplified model' (Kruss et al., 2015).

On the one hand, the impact of RU can lead to an increase in labour effectiveness, knowledge and technology transfer, as well as facilitation of entrepreneurship and use of scientific research. On the other hand - in social sphere - it can lead to an increase in social protection, non-commercial knowledge transfer, and an increase of cultural and social consumptionand the use of results of scientific research.

Another important consideration is the territoriality which can affect their institutional independence. The state financed higher education institutions are autonomous with independent study and research control. However, on a regional level the RU should be more integrated in the regional planning system, in order to create a more coherent organizational and financial management in both the study and research areas. The author of this research emphasize that such mechanisms can be generated to overcome institutional problems in the RU authonomy.

The second point of attention is that the RU are functioning within the scope of multiple territorial entities, i.e. - they are not limited to one region. The existence of a higher education institution within a certain area is an advantage factor over other regions and is an important resource for the specific community. It is challenging to manage different $\mathrm{RU}$ in different territorial areas of regions, in such a way that they would magnify each institution's performance and allow creating mechanism for fulfilling important tasks for the benefit of the region as well as help building national and international interinstitutional relations.

At the some time, the goals of the regions are to increase the well-being of the citizens and to reduce inequality, as noted by Sinkiene \& Grumadaite (2014). Knight (2012) has referred to RU target which is to practically use higher education as an instrument for regional development (Knight, 2012).

\section{Materials and Methods}

The research design is concentrated on the large scale and multilevel research methodology, while ensuring research limitations set based on the available information on comparable data on GDP in regions (NUTS 3) of Latvia in the period from 2010 to 2013.

Research methods: analysis of scientific research sources, comparison, systematization, generalization, descriptive statistic, correlation, and co-variation analysis.

Research limitations: the comparable GDP NUTS 3 regional data of Latvia is available only for the period of 2010-2013; therefore, further comparison and analysis was based on the data from this period, while only the RU of the particular country and their impact on the regional development of the particular regions were analyzed. Due to the limitations of this paper, the impact of RU on the regional development was evaluated from a limited perspective: the impact on the economic activity, impact on employment and unemployment, number of vacancies, salary of RHEI graduates, distribution of labour force according to the higher education in regions, according to the RU, graduate loyalty to the region and the base costs of RU programmes.

Authors chose the following methodology for determining the RU investments in the regional development on three levels:

(1) The first research level included research on regional understanding and regional problems related to the division of regions and the RU of Latvia. The latter is based on the Overview of the Higher Education System of Latvia in 2017. The territory of the European Union (EU), according to the European Parliament and Council Regulation of $26^{\text {th }}$ May 2013, can be divided in NUTS 1, NUTS 2, and NUTS 3 regions. Each territorial unit has its own unique code and name: (EUROSTAT, EC, 2011). In Latvia, the following territorial units are present: Kurzeme (LV003), Latgale (LV005), Riga (LV006), Pieriga (LV007), Vidzeme (LV008), Zemgale (LV009) un Latgale (LV009) (CSB, 2015). Within these territorial units currently six RU are present: Latvia University of Life Sciences and Technologies, (LLU); Daugavpils University (DU); Liepaja University (LiepU); Rezekne Academy of Technologies (RTA); Ventspils University of Applied Sciences (VeA); Vidzeme University of Applied Sciences (ViA) (LR IZM, 2016).

(2) The second research level included evaluation of employment and business activity in Latvia as well as the loyalty of graduates to each region. This research based by statistics of the Central Statistical Bureau of Latvia (LR CSB) and scientists' research.

(3) The third and fourth level of research help determine the impact of RU on the regional development, which the authors of the research 
carried out by performing correlation between the GDP and number of students active in Latvia. The results were further correlated with the average GDP per capita of the particular region's population, in order to evaluate the impact of RU on the regional development. Dispersion analysis was carried out to further examine this tendency, based on the Eurostat, LR CSB, Higher Education Monitoring and Analysis Centre of Lithuania (MOSTA) statistical data, Vidzeme University of Applied Sciences and the results of authors' researches.

To affirm the newly calculated results, the situation analysis was performed based on the theory, economic activity, increase of number of jobs, overall employment, unemployment, open job vacancies, salary, and analysis of the breakdown of labour force.

\section{Results and Discussion}

Multiple RU accept regionalism rhetoric with the term 'region' as an opposite to metropolitanism and cosmopolitanism. Undoubtedly, the term region can be attributed to a territory of substantially different space of area (Encyclopedia Britannica, 2017). It can be applied to the inner parts of the state, or greater national territories, while it span over state borders, thus accompanying multiple national territories. For instance the regions of Baltic, Scandinavia countries include statistical territorial classification units (NUTS). Thus, as a result, the regional role of RU can be interpreted differently. For instance, the RU can define itself as (1) regional, using the name of the area; (2) working on a regional level with the aim of fulfilling the labour market demands; (3) cooperating with regional research institutes and employer representative organizations; or (4) offer the regional society services and support centre. RU have many reasons to name themselves 'regional' universities according to the extent to which one of the priorities is their relations with the region and the interested parties. Thereby, it is clear that the question about the territoriality of RU is not flawless. It is important that everyone who is in contact with the RU would acknowledge the questions related to territoriality.

It should be noted that from all national universities of Latvia, the proportion of RU compromises around $21 \%$ of the total number of students in Latvia i.e. 5945 students which is by 5645 less than in 2015 (LR IZM, 2018).

The theory analysis indicated that education can cause positive impact on the unemployment (Glaeser, Giacomo \& Ponzetto, 2014); therefore it was necessary to examine the unemployment level in the regions of Latvia.

In the labour market of Latvia, the authors identified significant regional disparity between the capital city Riga, Pieriga and, most significantly, in comparison with Latgale region in both the aspects of employment and unemployment level, which is around 19\% (2010/13) (Latviete, Pilvere, 2010). When comparing the working age population with tertiary education, it can be seen that Riga and Pieriga regions attract ever larger number of enrollees (2015/18), by about 14.6 thousand. At the some time, in regions this increase $(2015 / 18)$ is minimal, only by $2-3$ thousand. In Latgale region there is the highest number of the employed people with higher education (CSB, 2018b). Despite this fact, in Latgale the economic activity is the lowest $(56.3 \%)$ and there is the highest level of registered unemployment (7.6\%), while in Riga and Pieriga regions the combined economic activity is $(68.6 \%)$ and unemployment $-3.3 \%$, which is a significant difference (CSB, 2018c).

The indications on the positive impact on education can be found in a research on regions of the US (Glaeser, Giacomo, \& Ponzetto, 2014), therefore authors chose to analyse the economic activity structure of regions of Latvia (Figure 1).

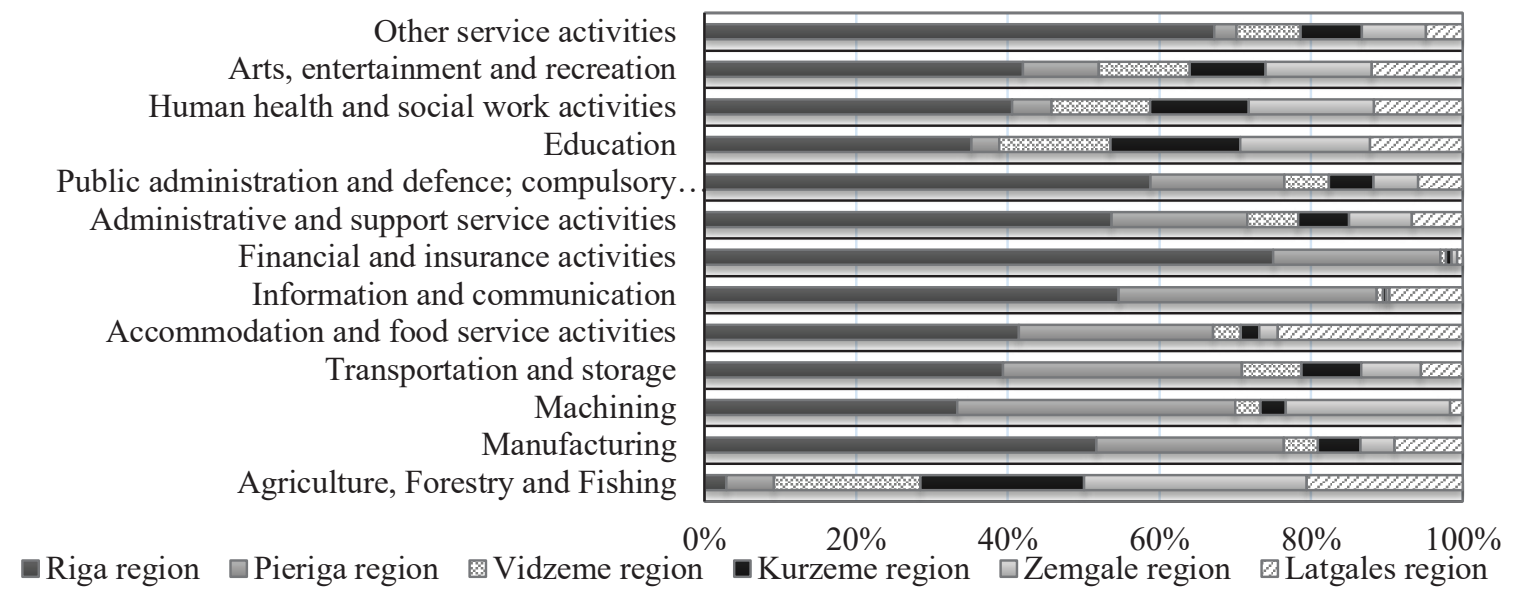

Figure 1. Distribution of economic activity in NUTS - 3 regions of Latvia by sectors, 2018, \% (CSP, 2018c; 2018d). 
In comparison with Riga and Pieriga, the activity in regions is dominated by financial and insurance services, information and communication, administrative and support services and other services. In comparison to the capital city and the neighbouring Jurmala, in the regions the existence of a significant proportion of secondary manufactory industry, metal working, machinery and logistics and other economic sectors (Figure 1) is relatively less likely to be observed.

In other regions the leading industries are agriculture, arts, entertainment and recreation, human health and social work activities, machining, and other services. In Riga and Pieriga regions there is the lowest unemployment level and the highest overall employability level nationwide due to the developing trade, transport, manufacturing, services and tourism sectors, which are further emphasized by the existence of the sea harbour (Pavlyuk, 2011; CSB, 2015).

The specialization goal of RU is to provide the necessary specialists to the particular region and its economic sectors. The theory has proved that education can cause economic activity, which is an investment in the development of the regional economics (Glaeser, Giacomo, \& Ponzetto, 2014).Among the entrepreneurs $48.6 \%$ have the bachelor's degree, while $22 \%$ master's degree (SSE Riga, 2011).

Nonetheless, the entrepreneurs are facing employee shortages. When comparing the ratio of vacancies in Riga and Pieriga with regions, it is 10 : 1 , while the largest deficit of workers can be seen in Latgale region. The lack of qualified workers can be observed not only in the large companies (69\%), but also in the medium (67\%) and small (59\%) enterprises and even in the microenterprises (39\%) (Zvirgzdina \& Jekabsone, 2016).

After studies, part of the graduates settle in the respective region where their RU is located, thus 'indicating loyalty' to its region: in Latgale $-74 \%$, Kurzeme - $66 \%$, in Zemgale $-49.4 \%$ of Latvian University of Agriculture, Vidzeme - 47.8\%, in Vidzeme region - 59.3\% (Vidzemes augstskola,
2016). Overall this is not a positive trend during the period of time with a labour deficit.

On the one hand, the graduates (incl. those of RU) lack job opportunities (youth unemployment is $30-$ $30.7 \%$ ), they are not satisfied with the salaries offered in the regions and they tend to find opportunities in the capital city or to emigrate. On the other hand, while in 2010 almost $27.1 \%$ of all employed of youth cohort received 150 - 300 euros has salary, then in 2013 there were only $19.2 \%$ in the same category. At the same time, the number of youth who received $700-$ 1000 euros has increased from 10.9 to $15.5 \%$, which indicates an overall increase of the number of highly qualified young people, whose impact on the regional economy increases proportionally, thus contributing to regional development (CSB, 2016a).

Taking into consideration that a higher salary in the regions can be received by the managers, senior specialists, and other highly qualified workers, the influence potential of the RU on the regional development is obvious. The distribution of labour force according to the education (bachelor's level) and sex (female/male \%) in regions is as follows: Latgale $17.5 / 11.5 \%$; Kurzeme - 14.8/10.4\%; Zemgale $14.3 / 9.7 \%$ and Vidzeme - 13.4/9.5\%, which indicates a balanced distribution, while in Riga and Pieriga 25.5/71.5\%. Labour force distribution with masters degree in regions by gender (female/male \%) is: Kurzeme $2.2 / 4.7 \%$ and Latgale $-2.0 / 4.9 \%$, while significantly less in Vidzeme - 1.1/3.3\%, meanwhile in Riga and Pieriga 25.5/63.4\%, which significantly influences the overall salary level (CSB, 2016b). The number of unemployed people with the higher education decreased in all regions, most significantly in Kurzeme region by 35\% (2012/13) (Zvirgzdina \& Jekabsone, 2016).

Research authors have conclude dthat not only the overall professional abilities of RU graduates increase, but also their compliance with the regional labour market needs; Nonetheless more progress is needed, which is evident by the surveys indicating the lack of highly qualified labour force. The distribution

Distribution of graduates in total and by gender at universities in the regions of Latvia (LR IZM, 2018)

\begin{tabular}{|l|c|c|}
\hline \multicolumn{1}{|c|}{ Regional University } & Total graduates & $\begin{array}{c}\text { Number of female } \\
\text { graduates }\end{array}$ \\
\hline Latvia University of Life Sciences and Technologies (LLU) & 629 & 332 \\
\hline Daugavpils University (DU) & 412 & 307 \\
\hline Liepaja University (LiepU) & 234 & 186 \\
\hline Rezekne Academy of Technologies (RTA) & 287 & 175 \\
\hline Ventspils University of Applied Sciences (VeA) & 160 & 96 \\
\hline Vidzeme University of Applied Sciences (ViA) & 175 & 97 \\
\hline
\end{tabular}


Estimation of homogeneity of GDP per capita in the NUTS 3 regions of Latvia by location of regional universities $(n=4) * *$

\begin{tabular}{|l|c|c|}
\hline \multirow{2}{*}{ NUTS_3 } & \multicolumn{2}{|c|}{ Subgroup Configurations* } \\
\cline { 2 - 3 } & 1 & 2 \\
\hline Vidzeme & 1171.2850 & $\mathrm{x}$ \\
\hline Latgale & 1490.4475 & $\mathrm{x}$ \\
\hline Zemgale & 1498.0750 & $\mathrm{x}$ \\
\hline Kurzeme & $\mathrm{x}$ & 1913.5400 \\
\hline Sig. & 0.0620 & 1.000 \\
\hline
\end{tabular}

* Subset for alpha $=0.05$

** Means for groups in homogeneous subsets are displayed.

of highly qualified (bachelor and master's degrees) labour force is in favour of Riga and Pieriga regions, most significantly in female cohort. Overall, there are more women with received qualification and degree also in regional universities (Table 1). This indicates the impact of the existing problems in the RU on the regional development.

In Latvia University of Life Sciences and Tehnologies and Vidzeme University of Applied Sciences (Table 1) the gender ratio is even, meanwhile the most unequal situation can be observed in Liepaja University and Daugavpils University, where the share of female graduates reaches $79.5 \%$ and $74.5 \%$, respectively.

The base costs of a single study place in the 2013 prices for bachelor's (academic and professional) education level on average were 1810.02 EUR, while for masters level - 2715.03 EUR per year (LR IZM, 2014), which can be considered to be an investment in the regional development. In Latvia similar to Lithuania, women more often have higher education (on average by $7 \%$ ) than men, thus they have predominance in the regions. Higher return is from RU graduates with engineering-technical degree, lower from arts and humanitarian degree owners; and while higher from individuals with master's degree in comparison with those with bachelor degree (MOSTA, 2015).

The dispersion analysis of the RU impact on regional development accounts to $\mathrm{p}$-value $=0.553$, thus with a $95 \%$ probability the zero hypothesis; that GDP per capita of the four NUTS 3 groups is similar can not be rejected.

Since the $p$-value $=0.01<0.05$, then with $95 \%$ probability the hypothesis, that GDP of all the NUTS groups are similar; can be rejected. At the same time it can be seen (Table 2) that there are homogenous subgroups in which the average values do not differ.

The correlation between the regional (NUTS 3) GDP per person in regions of Latvia with the number of RU students $(2010 / 13)$ correlation $r=0.979, p=0.01$,
$\mathrm{R}^{2}=0.9593$, but $\mathrm{t}=6.450>0.679$, then with significance level $\alpha=0.001$ or probability $\mathrm{P}=1-\alpha=0.979$ it can be assumed that there is a greater possibility of a significant positive linear connection between the GDP and the number of RU students. Statistically significant direct relations can be observed. Analysis of covariance indicated that the number of students of RU influence the GDP, [F (2.34) $=245.585$, $\mathrm{p}<0.00]$.

In order to confirm the interrelations, the authors carried out analysis of changes in the number of students. Due to economic and demographic aspects, migration as well as RU competition the overall shrinkage in the number of students at the RU - in $2014 / 15$. academic year was by 5 to $12 \%$, while the overall number of enrolled students has shrunk by 20\% (LR IZM, 2016).

Authors conclude that the impact of RU on the regional development has a tendency to decriase, mainly to the reason that the general population is decreasing, incl. of students. Theory explaines it through personal and social socioeconomic spheres and their interactions (IHEP, 1998; Knight, 2012; Universities UK, 2015).

\section{Conclusions}

1. The contribution of RU to the regional development was proved in the following instances: (1) by encouraging entrepreneurship, preparing the necessary specialists and entrepreneurs for regions; (2) reducing unemployment level; (3) the loyalty of RU students towards their region's national average $-59.3 \%$; (4) the qualification of RU graduates is increasing along with salary; (5) increased conformity of the RU graduates skills with the regional labour demand according to the economic sectors; (6) in Latvia, the same as in Lithuania, the return of education is higher for women (by average 7\%) than for the men.

2. Significant problems can be observed in the process of RU impact on the regional development: (1) theoretical problems: terminological inaccuracies 
in the use of word 'region' when attributing it to a certain territory in relation to RU zones of impact; (2) problems with RU autonomy and cohesion of needs of the region; (3) reducing number of RU students; (4) around 40.7\% RU students are not loyal to the region of their university and move to Riga, Pieriga or migrate abroad; (5) the region lacks specialists; (6) analysing the labourforce distribution by according to education (with bachelor's degree), the lowest number is in Vidzeme; (6) in the regions of Latvia more women than men have a degree (procentage-wise) while in Riga and Pieriga $71.5 \%$ men have the bachelor's degree, the opposite situation is with the master's degree - out of $3.3 \%$ of labour force with the master's degree, $63.4 \%$ are men, which affects the salary depending on the gender; (7) the overall return of investment from the possession of a higher education degree in the regions for men is reduced due to fact that there are fewer men, although the return for RU graduates with engineering degrees is higher.

3. The analysis of RU investment in to the regional development indicated that there is a close positive correlation 0.979 between the number of RU students and GDP per inhabitant from regions of Latvia (four NUTS 3). Due to economic and, demographic reasons, as well as migration and RU competition, a significant reducation of overall number of enrolling students can be seen, consequently, the impact of RU on the regional development has been reduced and, as a result, the decrease in the number of students negatively affects the business activity.

\section{References}

1. Bashir, M., Iqbal, M., \& Zaman, K. (2011). Estimating private rate of return on higher education in Pakistan. Review of Economic and Business Studies, 4(1), 179-197.

2. Baumanis, A. (2004). Expenditure for education and their role in socio-economic development. In the $5^{\text {th }}$ internationa.conference. Entrepreneurship: Possibilities, Problems and their Solutions in the Presence of Globalization Collection of Articles, 23 April 2004 (pp. 21-30). Riga: School of Business Administration Turiba.

3. Beeson, M. (2010). Asymmetrical Regionalism: China, Southeast Asia and Uneven Development. East Asia, 27(4), 329-343. DOI: 10.1007/s12140-010-9121-0.

4. Bouaissa, M. (2009). Human capital theory returns to education and on the job learning: evidence from the Canadian data, preliminary and incomplete version. In CEA, 43 ${ }^{\text {rd }}$ Annual Conference, 29-31 May, 2009, Ontario: Toronto University.

5. Chadwick, G. (2016). Models of urban \& regional systems in developing countries: some theories and their application in physical planning. Urban and Regional Planning Series, (36). New York: Pergamon Press.

6. CSB (Central statistics bureau of Latvia). (2015). Par statistiskajiem regioniem (About the statistical regions). Retrieved April 12, 2019, from http://www.csb.gov.lv/dokumenti/par-statistiskajiemregioniem-28607.html. (in Latvian)

7. CSB (Central statistics bureau of Latvia). (2016a). Darba samaksa. DSG13. Darba ņēmēju skaita sadalījums pēc darba ienākumiem pa vecuma grupām (Labour costs. DSG13. Number of employees grouped according to the average income categories by age groups). Retrieved April 12, 2019, from http://data.csb.gov.lv/pxweb/ lv/Sociala/Sociala_ikgad_dsamaksa/DS0130_euro.px/table/tableViewLayout2/?rxid=cdcb978c-22b0416a-aacc-aa650d $3 \mathrm{e} 2 \mathrm{ce} 0$. (in Latvian)

8. CSB (Central statistics bureau of Latvia). (2016b). Employees by regions, educational attainment and sex on October 31, 2014. Retrieved April 12, 2019, from http://www.csb.gov.lv/sites/default/files/nr_18_ darba_samaksas_strukturas_apsekojuma_rezultati_2014_gada_16_00_lv_en.pdf.

9. CSB (Central statistics bureau of Latvia). (2018a). B030c. NB030c. Population by labour status, education, sex and quarter. Retrieved April 12, 2019, from https://data1.csb.gov.lv/pxweb/lv/sociala/ sociala_nodarb_aktivitate_isterm/NB030c.px/table/tableViewLayout1/?rxid=add3c5c3-6114-4ba0a20d-2a143886625 d.

10. CSB (Central statistics bureau of Latvia). (2018b). NBG351. Population by labour status, education and region. Retrieved April 12, 2019, from https://data1.csb.gov.lv/pxweb/lv/sociala/sociala_nodarb_ aktivitate_ikgad/NBG351.px/table/tableViewLayout1/?rxid=add3c5c3-6114-4ba0-a20d-2a143886625 $\overline{\mathrm{d}}$.

11. CSB (Central statistics bureau of Latvia). (2018c). NBG030. Population by labour status and statistical region. Retrieved April 12, 2019, from https://data1.csb.gov.lv/pxweb/lv/sociala/sociala_nodarb aktivitate_ikgad/NBG030.px/table/tableViewLayout1/?rxid=add3c5c3-6114-4ba0-a20d-2a143886625 $\overline{\mathrm{d}}$.

12. CSB (Central statistics bureau of Latvia). (2018d). SRG010. Economically active enterprises in statistical regions, cities under state jurisdiction and counties. Retrieved April 12, 2019, from https://data1.csb.gov. 
lv/pxweb/en/uzn/uzn_01_skaits/SRG010.px/table/tableViewLayout1/?rxid=db5515ed-67c7-481e-ad70$92 \mathrm{e} 6 \mathrm{e} 840 \mathrm{~b} 09 \mathrm{c}$.

13. Ekmanis, J. (2005). Zinātnes attīstības tendences mūsdienu Latvijā. Stratēgeiskās analīzes komisija. Zinātniski pētnieciskie raksti. Zināšanu sabiedrību veidojot (Science development tendencies in present Latvia strategic analysis commission. Scientific research articles). Developing Knowledge Society. Nr. 2 (3), 30 39. lpp. Riga: Zinatne. (in Latvian)

14. Encyclopedia Britanica (2017). Region. Retrieved April 12, 2019, from https://www.britannica.com/ science/region-geography.

15. EUROSTAT, (EC) European Commission (2011). Regions in the European Union - Nomenclature of territorial units for statistics NUTS 2010/EU-27, General and regional statistics. Methodologies \& Working papers, p.143. Luxembourg: Publications Office of the European Union.

16. Glaeser, E.L., Giacomo, G.A.M., \& Ponzetto, K. (2014). Cities, skills and regional change. Regional Studies, 48 (1), 7-43. Taylor \& Francis Online.

17. Grizane, T., Sannikova, A., \& Jasaitis, J. (2017). Impact of regional higher education intitutions on the convergence of regions. In: 18th International Scientific Conference. Proceedings of the 2016 International Conference Economic Science of Rural Development, 27-28 April 2017 (pp. 44-5). Latvia, Jelgava: LLU.

18. IHEP (1998). Reaping the Benefits: Defining the Public and Private Value of Going to College, the New Millennium on Higher Education Costs, Pricing and Productivity. Washington, DC: Institute for Higher Education Policy.

19. LR IZM (Latvijas republikas izglītības ministrija). (2014). Pētījums par studiju izmaksu koeficientu augstākajā izglìtībā aktualizēšanu un priekšlikumu sagatavošana to konsolidēšanai. RTU (Study on updating of higher education study cost ratios and preparing proposals for their consolidation). Retrieved December 12, 2018, from http://www.izm.gov.lv/images/izglitiba_augst/5_pielik_koefic.893.pdf. (in Latvian)

20. LR IZM (Latvijas Republikas izglītîbas ministrija). (2016). Pārskats par Latvijas augstāko izglītību 2015. gadā. Galvenie statistikas dati (Report on Latvian Higher Education in 2015. Key statistics). Retrieved May 21, 2019, from http://www.izm.gov.lv/images/izglitiba_augst/Parskats_2015.pdf. (in Latvian)

21. LR IZM (LR IZM (Latvijas Republikas izglīīibas ministrija). (2018). Pārskats par par Latvijas augstāko izglìt̄ibu 2017.gadā. Galvenie statistikas dati. (Overview of Higher Education in Latvia 2017. Main statistical data). Retrieved December 12, 2018, from https://www.izm.gov.lv/images/izglitiba_augst/ Parskats-par-Latvijas-augstako-izglitibu-2017gada.pdf. (in Latvian)

22. Knight, J. (2012). A Conceptual Framework for the Regionalization of Higher Education: Application to Asia, in Higher Education Regionalization in Asia Pacific. In J.N. Hawkins, K.H. Mok, \& D.E. Neubauer (Eds.), Implications for Governance, Citizenship and University Transformation, (pp. 17-35). New York: Palgrave Macmillan. DOI: 10.1057/9781137311801.0008.

23. Kruss, G., McGrath, S., Petersen, I., \& Gastrow, M. (2015). Higher education and economic development: The importance of building technological capabilities. International Journal of Educational Developmen, 43, 22-31. DOI: 10.1080/0376835x.2016.1156518.

24. Latviete, I., \& Pilvere, I. (2010). Social policy in the employment field in Latvia after league European Union. Business and Management. 2010. Selected papers, 658-666. Lithuania: Vilnius. Available at http:// www.researchgate.net/publication/228764560_SOCIAL_POLICY_IN_THE_EMPLOYMENT_FIELD_ IN_LATVIA_AFTER_LEAGUE_EUROPEAN__UNION. DOI: $10 . \overline{3} 84 \overline{6} / \mathrm{bm} . \overline{2} 010.087$.

25. Mankiw, G.N., Romer, D., \& Weil, D.N. (1992). Contribution to the Empirics of Economic Growth. The Quarterly Journal of Economics, 107i2, 407-437. DOI: 10.3386/w3541.

26. McMahon, W. (1998). Education and growth in East Asia. Economics of Education Review, 17(2), 159172.

27. MOSTA (2015). Effectiveness of higher education - overview and recommendations. Policy brief. DOI: 10.1016/s0272-7757(97)00050-2. Retrieved December 12, 2018, from http://mosta.lt/images/leidiniai/ Effectiveness_of_higher_education_Policy_brief.pdf.

28. NAP (2012). National Development Plan of Latvia 2014.-2020 (NAP). Retrieved May 12, 2019, from http://www.nap.lv/images/20121220_NAP2020_Saeim\%C4\%81_apstiprin\%C4\%81ts.pdf.

29. O'Carroll, C., Harmon, C., \& Farrell, L. (2006). The economic and social impact of higher education. Dublin: Irish Universities Association. 
30. Odit, M., Dookhan, K., \& Fauzel, S. (2010). The impact of education on economic growth. The Case of Mauritius. International Business and Economics Research Journal, 9(8), 141-152. DOI: 10.19030/iber. v9i8.620.

31. OECD (Organization for Economic Co-operation and Development) (2007) Higher Education and Regions: Globally Competitive, Locally Engaged. Paris: Organization for Economic Cooperation and Development.

32. Pavlyuk, D. (2011). Spatial analysis of regional employment rates in Latvia. Sustainable spatial development, (2), 56-62. Retrieved May 12, 2019, from https://ortus.rtu.lv/science/en/publications/11995/ fulltext.

33. Sinkiené, J., \& Grumadaité, K. (2014). Sumanaus regiono konceptualus modelis (A conceptual model for a smart region). Viešoji politika ir administravimas, 13 (3), 414-426. DOI: 10.5755/j01.ppaa.13.3.8305. (in Lithuanian)

34. SSE Riga (2011). Nordea vitamers - biznesa vitalitātes novērtējums. Latvijas uzn̄ēmumu konkurētspēja (Nordea vitametrs - Business Vitality Assessment. Competitiveness of Enterprises of Latvia). Riga: SSE. (in Latvian)

35. Universities UK (2015). The economic role of UK universities. The Funding Environment. Retrieved December 18, 2018, from http://www.universitiesuk.ac.uk/policy-and-analysis/reports/Documents/2015/ the-economic-role-of-uk-universities.pdf.

36. Vidzemes Augstskola (2016). Valmierā un Vidzemes reǵionā piedāvātās izglīîibas atbilstība uzṇēmēju pieprasījumam un nodarbinātības prognozēm. Valmieras pilsētas pašvaldības granta pētījums (Development of education offered in Valmiera and Vidzeme region and how meets the demands of entrepreneurs and employability forecasts. Valmiera municipality grant research). Retrieved April 12, 2019, from http:// www.valmiera.lv/images/userfiles/cits/Petijums_Darba_tirgus_01_02.pdf. (in Latvian)

37. Zvirgzdina, R., \& Jekabsone, I. (2016). Unemployment problems in the regions of Latvia. In Proceedings of the 2016 International Conference Economics for Rural Development, 21-22 April 2016 (41), (pp. 195202). Jelgava: LLU ESAF. 